\title{
Financial Effectiveness of Greek Municipalities: An Empirical Investigation
}

\author{
Christos Pallis \\ Panteion University, Kallithea, Greece \\ Petros Pallis \\ University of Piraeus, Piraeus, Greece
}

\begin{abstract}
Municipalities are autonomous economic and administrative entities, with common actions and responsibilities. Moreover, all Municipalities are quite different considering specific characteristics, such as geographic, demographic, and economic. The aim of this research is to separate the entire sample of Municipalities in Greece into categories, based on the effectiveness of financial management and financial performance into effective and ineffective ones. For the separation of the sample into groups, cluster analysis was preferred. For this reason, three variables were used: the lending capacity of the Municipality, flexibility in making non-investment costs, and flexibility in investment spending. These three variables were considered to be the key dimensions of effectiveness in financial management and therefore their use, representatively describes the effectiveness of Greek Municipalities. Thus, this paper presents the literature review of the financial effectiveness of Municipalities and the methodology of an empirical research through structured questionnaire that was sent to the entire population of Greek Municipalities, characterized in this way with considerable heterogeneity. In this way, it investigates the views of Mayors in the two categories of Municipalities (effective and non effective financial management and financial performance) as regards: (a) the biggest problems faced by the citizens in their Municipality, and (b) the biggest personnel problems faced by their Municipality. Concluding, the prioritization of both problems seems to be the same for both groups of Municipalities. The frequency of responses differs slightly and differences are not so large that financial performance can be considered to affect respondents' opinions.
\end{abstract}

Keywords: Greek Municipalities, local development, public finance, financial performance, financial management, empirical investigation

\section{Introduction}

Municipalities are autonomous economic and administrative entities, with common actions and responsibilities. However, not all Municipalities are the same when considering specific geographic, demographic, economic, and other characteristics (Pallis, 2011). In Greece, the institutional framework surrounding local authorities prevented them from playing an essential role, due to their limited responsibilities and economic means (L. C. Pallis \& L. P. Pallis, 2013).

Christos Pallis, Ph.D., researcher, Department of Public Management, Panteion University, Kallithea, 17671, Attica, Greece. Petros Pallis, Ph.D. student, researcher, University of Piraeus, Piraeus, Greece.

Correspondence concerning this article should be addressed to Christos Pallis, 25 Hronopoulou str. Alimos, 17455, Attica, Greece. 
The manpower or else human resources are the most valuable asset today for an organization whether it is public or private. Managing of human resources includes recruitment, selection, development, and adaptation of human resources in the workplace in order to increase their working capacity and efficiency.

The objectives should be the management of human resources in public administration, particularly in local authorities:

- Improve the quality of service and productivity;

- Job satisfaction and staff development;

- Achieving economic and social objectives.

To achieve these objectives, effective management of local authorities implies faithful implementation of the principles contained in the individual principles of administration as:

- Mobilizing leadership;

- Mobilizing workers;

- Create a positive organizational culture;

- Vision, faith, and enthusiasm (Papalexandri, 2011).

In this context, Municipalities today face the challenge of restructuring their structures and their staff to provide quick services to its citizens and ultimately of growth and social cohesion. Under this light, two basic questions emerge, which are the main subject of the investigation and require special evaluation and utilization by both Municipalities and the central government's planned strategy for the new modern and efficient local authority:

- The biggest problems faced by the citizens in their Municipality;

- The biggest personnel problems faced by their Municipality.

Moreover, the aim of this research is to divide the entire sample of Municipalities in Greece into categories, based on the efficiency of financial management: efficient and inefficient Municipalities. Cluster analysis was used to separate the sample into groups. Three variables were used to create the clusters in this research: a Municipality's borrowing capacity, flexibility in non-investing costs, and flexibility in investing costs. These three variables were considered to be the key dimensions of efficiency in financial management; therefore, their use is illustrative of the efficiency or inefficiency of Greek Municipalities (L. C. Pallis \& L. P. Pallis, 2014).

In this research, it identifies differences between the characteristics of the two categories, as regards the two mentioned questions. So far, no research has been done, on the above questions at such sample level as used in this research, i.e., all the Municipalities in the territory of Greece.

The following chapter will present the literature review regarding financial capability of Municipalities. The third chapter will present the methodology used, including a description of the sampling and data collection process, determination of the population, specification of the scope of the sample, definition of the sampling unit, etc. The fourth chapter will present the results of the methodology used and the fifth will present the results of data analysis. Finally, the sixth chapter will set out the overall conclusions of the research.

\section{Literature Review}

The aim of this research is to separate the entire sample of Municipalities in Greece into categories, based on the effectiveness of financial management and financial performance into effective and ineffective ones. For this reason, three variables were used: 
- The lending capacity of the Municipality;

- Flexibility in making non-investment costs;

- Flexibility in investment spending.

Cohen, Doumpos, Neofytou, and Zopounidis (2012) built an operational model for evaluating the financial viability of local Municipalities in Greece. In particular, an evaluation model is developed on the basis of accrual financial data from 360 Greek Municipalities in 2007. A set of models customized to the local government context financial ratios defines that rate Municipalities distinguish those with good financial condition from those experiencing financial problems.

Cabaleiro, Buch, and Vaamonte (2014) noted that financial condition of local institutions is a term closely linked to the concept of fiscal health and Wang, Dennis, and Tu (2007) pointed out that this concept represents the ability of an organization to meet its financial obligations on time. As financial condition is a concept that is not directly observable, literature has focused on assessing the different aspects or dimensions that compose it (Cabaleiro et al., 2014). Groves, Godsey, and Shulman (1981) noted that financial condition is composed of:

- Cash solvency (government's capacity to generate enough cash or liquidity to pay its bills);

- Budgetary solvency (the city's ability to generate sufficient revenues over its normal budgetary period to meet its expenditure obligations and not incur deficits);

- Long-run solvency (the long-run ability of a government to pay all the costs of doing business, including expenditure obligations that normally appear in each annual budget, as well as those that show up only in the years in which they must be paid);

- Service-level solvency (it refers to whether a government can provide the level and quality of services required for the general health and welfare of a community).

Additionally, financial effectiveness is associated to cost efficiency, as the empirical study of 108 Italian major Municipalities stated (Storto, 2016) or in a broad panel of German Municipalities has investigated (Geys, Heinemann, \& Kalb, 2010). In further studies, Athanassopoulos, Triantis, and Schmidt (1998); Balaguer-Coll, Prior, and Tortosa-Ausina (2007); De Borger and Kerstens (1996); and Loikkanen and Susiluoto (2005) analyzed the general determinants of local governments' cost efficiency in Greece, Spain, Belgium, and Finland - using different parametric and non-parametric estimation techniques. They all came to the conclusion that (intergovernmental) grants stimulate technical or cost inefficiency (Kalb, 2010). Moreover, the increase in slack costs due to Municipality amalgamation, which is pushed forward in several countries to achieve economies of scale, is examined. Employing the stochastic frontier cost function to estimate the inefficiency of local public expenditure due to slack, a study investigated 479 Japanese Municipalities that had amalgamated from 2000 to 2005 . The estimation results showed that Municipality amalgamation produces integration costs (slack) in an administrative organization (Nakazawa, 2013).

Financial effectiveness is also associated to the effectiveness of public expenditure and consequently to the quality of services offered to citizens. The study suggests that a trade-off between expenditure efficiency and effectiveness, i.e., the quality of public service seems to exist (Storto, 2016). Silkman and Young (1982) showed that the non-local proportion of total revenues (that is the proportion of intergovernmental grants) has a strong negative impact on the productive efficiency of local government's services. Bessho and Ogawa (2015) suggested that the current grants system discourages Municipalities from increasing their own-source revenue. Furthermore, Municipalities can induce grants by expanding government current expenditure. 


\section{Research Methods}

\section{General}

This chapter presents the research methodology adopted in conducting this empirical project. More specifically, it includes: (a) the definition of population and the study sample; (b) the data collecting method; (c) the response to the survey and the characteristics of Municipalities participating; and (d) the process whereby the research tool used to collect data was created (structured questionnaire) and its analytical presentation.

\section{Sampling and Data Collection Process}

The process of choosing the sample and collecting data is complex and includes six stages (Stathakopoulos, 2001): definition of population, determination of the sampling frame, definition of sampling unit, choice of sampling method, determination of sample size, and implementation. From this process, a number of respondents will participate in the survey emerges.

\section{Definition of Population}

The first and most important step in the primary data collection process is to define characteristics on the basis of which the population to be examined will be defined (Churchill \& Iacobucci, 2002). The full definition of the population requires the inclusion of four basic parameters: the item, the sampling unit, the extent of the sampling, and the time (Parasuraman, Grewal, \& Krishnan, 2004). The item and sampling unit in this survey are defined as the Municipalities of Greece, the extent of sampling concerned the whole of the Greek state and the time it was conducted was from 10 June, 2010 to 30 September, 2010. Communities in Greece were excluded from the population in the survey due to their small size and different needs in relation to the Municipalities. So in the end, the survey's population was defined as being the 914 Greek Municipalities throughout the state, as recorded in the 2001 inventory of the National Statistical Service (Pallis, 2011).

\section{Determination of the Sampling Frame}

The next step, after defining the population to be examined, is to locate a sampling frame which must be composed of the fullest and most accurate inventory possible of members of the population to be examined (Churchill \& Iacobucci, 2002). The sampling frame used in this survey was the most recent inventory of the National Statistical Service (2001) which includes the census of the population of Greece based on geographical districts, prefectures, Municipalities, and communities.

\section{Definition of the Sampling Unit}

The sampling units were defined as being the Greek Municipalities. As regards the respondents from whom survey data were collected, the "key informant method" was used, meaning the person in the survey unit (Municipality of Greece) who had the greatest knowledge of the subject of the survey. This method reduces to a satisfactory degree any concerns regarding the reliability of answers given by respondents, as the respondent chosen in each unit is the best available person with knowledge of the data that must be collected through the survey (Phillips, 1981; Kumar, Stern, \& Anderson, 1993). In this survey, the key informant was chosen to be the mayor in each Municipality examined.

\section{Choice of Sampling Method}

Sampling methods considerably affect the possibility of generalizing the results. In order that the results emerging in the sample might be generalized throughout the total population, a probability sample must be used (Kinnear \& Taylor, 1987) in which each unit in the sample has an equal chance of being selected from the 
population. The safest way of producing a probability sample is the population census and the definition of the total census as a sample in the survey (Stathakopoulos, 2001). This method was followed in this survey, ensuring the generalization of results.

\section{Determination of Sample Size}

As a result of the census method, the size of the sample coincides with the size of the population in the 914 Municipalities recorded in the inventory of the National Statistical Service (2001).

\section{Implementation}

With reference to conducting the survey, the two following sub-paragraphs explain the method of contact with the respondents and the reasons they were finally chosen, as well as the results of the method.

\section{Method of Contact}

Completion and collection of questionnaires were carried out during the period from 10 June, 2010 to 30 September, 2010 in one phase with the use of self-completion questionnaires. The sample in the survey (which coincides with the population in the survey) is characterized by considerable heterogeneity, as it has been specified that it will be all the Municipalities in Greece. The choice of such a kind of sample contributes to the chance of generalizing the results of the survey, as in order for the results of a survey to be generally applicable, heterogeneous samples are preferred (Hooley, Lynch, \& Shepherd, 1990; Kohli \& Jaworski, 1990; Narver \& Slater, 1990; Ruekert, 1992).

Sampling units were approached by mail. This took the form of the delivery of the questionnaire along with an accompanying letter to each Municipality, for the attention of the mayor, by mail, email, or fax, which explained to the recipient the purpose of the survey. This was preceded by telephone contact regarding the dates the questionnaire would be delivered and handed back. This method obliged the respondent to respond within a fixed time (Stathakopoulos, 2001). Respondents returned the completed questionnaires using the same method, via mail, email, or fax, on the dates specified. The choice of only one respondent from each sampling unit (key-informant) involves the risk of collecting information that bears no relation to reality, but reflects his personal views. However, the achievement of research objectives required that the respondent be the mayor in each Municipality, so he was in a position to speak about them accurately and in detail.

\section{Research Results}

The method of collecting data that was used, in the end brought about the collection of questionnaires from 299 Municipalities out of the total of 914 that had been specified as the sample population. This result provides a response percentage of $33 \%$ which is considered quite satisfactory, on the basis of the method adopted (Kinnear \& Taylor, 1987). As is described in Table 1, 299 Municipalities responded to the survey represent the total population as there was good stratification and representation from all Prefectures in Greece with fairly satisfactory response percentages in each Prefecture. The Greek Municipalities that finally answered the questionnaire represent all the Municipalities in Greece as there was no Prefecture in which the individual response percentage was not satisfactory. Out of the 299 questionnaires collected, 41 were excluded from the analyses due to a large number of answers to questions that would have reduced the statistical reliability of the findings. Additionally, in these 41 excluded questionnaires, cases were observed in which the respondents misinterpreted the hierarchical questions. In the end, out of the 299 questionnaires, 258 exploitable ones were 
taken into account in the survey (87\%), a number which is statistically acceptable (e.g., Hooley et al., 1990; Kohli \& Jaworski, 1990; Narver \& Slater, 1990; Ruekert, 1992).

Table 1

Respondents per Prefecture

\begin{tabular}{|c|c|c|c|c|c|c|c|}
\hline $\begin{array}{l}\text { Geographical } \\
\text { districts }\end{array}$ & Prefectures & $\begin{array}{l}\text { Municipalities } \\
\text { participation } \\
\text { (number) }\end{array}$ & $\begin{array}{l}\text { Total number } \\
\text { of } \\
\text { Municipalities }\end{array}$ & Response & $\begin{array}{l}\text { Municipalities } \\
\text { participation } \\
\text { (population) } \\
\end{array}$ & $\begin{array}{l}\text { Total } \\
\text { population of } \\
\text { Municipalities }\end{array}$ & Response \\
\hline \multirow{4}{*}{ Attica } & Athens & 24 & 48 & $50 \%$ & $1,111,093$ & $2,664,776$ & $42 \%$ \\
\hline & Eastern Attica & 9 & 26 & $35 \%$ & 212,327 & 365,731 & $58 \%$ \\
\hline & Western Attica & 5 & 12 & $42 \%$ & 115,702 & 150,847 & $77 \%$ \\
\hline & Piraeus & 9 & 16 & $56 \%$ & 319,164 & 540,540 & $59 \%$ \\
\hline Subtotal & & 47 & 102 & $46.07 \%$ & $1,758,286$ & $3,721,894$ & $47.24 \%$ \\
\hline \multirow{6}{*}{$\begin{array}{l}\text { Rest of central } \\
\text { Greece and } \\
\text { Euboea }\end{array}$} & Etoloakarnania & 7 & 29 & $24 \%$ & 75,881 & 224,429 & $33.81 \%$ \\
\hline & Boeotia & 7 & 18 & $39 \%$ & 68,524 & 125,681 & $54.52 \%$ \\
\hline & Euboea & 9 & 25 & $36 \%$ & 31,968 & 212,993 & $15.01 \%$ \\
\hline & Evrytania & 5 & 11 & $45 \%$ & 12,542 & 32,053 & $39.13 \%$ \\
\hline & Fthiotida & 9 & 23 & $39 \%$ & 42,466 & 177,631 & $23.91 \%$ \\
\hline & Fokida & 4 & 12 & $33 \%$ & 15,190 & 48,284 & $31.46 \%$ \\
\hline Subtotal & & 41 & 118 & $34.74 \%$ & 246,571 & 821,071 & $30.03 \%$ \\
\hline \multirow{7}{*}{ Peloponnes } & Argolida & 6 & 14 & $43 \%$ & 52,326 & 104,323 & $50.16 \%$ \\
\hline & Arcadia & 7 & 22 & $32 \%$ & 28,055 & 101,444 & $27.66 \%$ \\
\hline & Achaia & 7 & 21 & $33 \%$ & 27,611 & 321,389 & $8.59 \%$ \\
\hline & Ilia & 5 & 22 & $23 \%$ & 7,849 & 193,288 & $4.06 \%$ \\
\hline & Corinthia & 6 & 15 & $40 \%$ & 87,142 & 154,624 & $56.36 \%$ \\
\hline & Laconia & 9 & 20 & $45 \%$ & 32,404 & 97,966 & $33.08 \%$ \\
\hline & Messinia & 6 & 29 & $21 \%$ & 72,767 & 175,213 & $41.53 \%$ \\
\hline Subtotal & & 46 & 143 & $32.16 \%$ & 308,154 & $1,148,247$ & $26.84 \%$ \\
\hline \multirow{4}{*}{ Ionian Islands } & Zakinthos & 2 & 6 & $33 \%$ & 16,475 & 39,015 & $42.23 \%$ \\
\hline & Corfu & 4 & 13 & $31 \%$ & 18,279 & 110,317 & $16.57 \%$ \\
\hline & Cefalonia & 4 & 8 & $50 \%$ & 14,448 & 38,435 & $37.59 \%$ \\
\hline & Lefkada & 2 & 6 & $33 \%$ & 4,444 & 21,843 & $20.35 \%$ \\
\hline Subtotal & & 12 & 33 & $36.36 \%$ & 53,646 & 209,610 & $25.59 \%$ \\
\hline \multirow{4}{*}{ Epirus } & Arta & 2 & 13 & $15 \%$ & 9,126 & 75,634 & $12.07 \%$ \\
\hline & Thesprotia & 2 & 8 & $25 \%$ & 9,527 & 43,071 & $22.12 \%$ \\
\hline & Ioannina & 10 & 28 & $36 \%$ & 25,967 & 165,500 & $15.69 \%$ \\
\hline & Preveza & 2 & 8 & $25 \%$ & 14,385 & 58,304 & $24.67 \%$ \\
\hline Subtotal & & 16 & 57 & $28.07 \%$ & 59,005 & 342,509 & $17.23 \%$ \\
\hline \multirow{4}{*}{ Thessaly } & Karditsa & 6 & 20 & $30 \%$ & 32,286 & 127,774 & $25.27 \%$ \\
\hline & Larissa & 9 & 28 & $32 \%$ & 173,782 & 272,966 & $63.66 \%$ \\
\hline & Magnesia & 8 & 22 & $36 \%$ & 22,214 & 202,632 & $10.96 \%$ \\
\hline & Trikala & 7 & 23 & $30 \%$ & 64,352 & 134,963 & $47.68 \%$ \\
\hline Subtotal & & 30 & 93 & $32.25 \%$ & 292,634 & 738,335 & $39.63 \%$ \\
\hline \multirow{5}{*}{ Macedonia } & Grevena & 4 & 8 & $50 \%$ & 17,273 & 35,255 & $48.99 \%$ \\
\hline & Drama & 2 & 8 & $25 \%$ & 11,215 & 103,545 & $10.83 \%$ \\
\hline & Imathia & 4 & 12 & $33 \%$ & 52,620 & 143,618 & $36.64 \%$ \\
\hline & Thessaloniki & 14 & 45 & $31 \%$ & 263,496 & $1,057,825$ & $24.91 \%$ \\
\hline & Kavala & 4 & 11 & $36 \%$ & 89,436 & 145,054 & $61.66 \%$ \\
\hline
\end{tabular}


Table 1 continued

\begin{tabular}{|c|c|c|c|c|c|c|c|}
\hline $\begin{array}{l}\text { Geographical } \\
\text { districts }\end{array}$ & Prefectures & $\begin{array}{l}\text { Municipalities } \\
\text { participation } \\
\text { (number) }\end{array}$ & $\begin{array}{l}\text { Total number } \\
\text { of } \\
\text { Municipalities }\end{array}$ & Response & $\begin{array}{l}\text { Municipalities } \\
\text { participation } \\
\text { (population) }\end{array}$ & $\begin{array}{l}\text { Total } \\
\text { population of } \\
\text { Municipalities }\end{array}$ & Response \\
\hline \multirow{8}{*}{ Macedonia } & Kastoria & 2 & 12 & $17 \%$ & 6,117 & 52,063 & $11.75 \%$ \\
\hline & Kilkis & 4 & 11 & $36 \%$ & 35,481 & 88,654 & $40.02 \%$ \\
\hline & Kozani & 6 & 16 & $38 \%$ & 75,182 & 152,138 & $49.42 \%$ \\
\hline & Pella & 3 & 11 & $27 \%$ & 51,276 & 145,797 & $35.17 \%$ \\
\hline & Pieria & 3 & 13 & $23 \%$ & 21,074 & 129,846 & $16.23 \%$ \\
\hline & Serres & 5 & 22 & $23 \%$ & 88,768 & 197,774 & $44.88 \%$ \\
\hline & Florina & 2 & 8 & $25 \%$ & 17,267 & 51,770 & $33.35 \%$ \\
\hline & Chalkidiki & 3 & 14 & $21 \%$ & 14,166 & 104,894 & $13.51 \%$ \\
\hline Subtotal & & 56 & 191 & $29.31 \%$ & 743,371 & $2,408,233$ & $30.87 \%$ \\
\hline \multirow{3}{*}{ Thrace } & Evros & 4 & 13 & $31 \%$ & 26,207 & 149,354 & $17.55 \%$ \\
\hline & Xanthi & 2 & 7 & $29 \%$ & 52,270 & 97,525 & $53.60 \%$ \\
\hline & Rodopi & 4 & 9 & $44 \%$ & 62,770 & 104,854 & $59.86 \%$ \\
\hline Subtotal & & 10 & 29 & $34.48 \%$ & 141,247 & 351,733 & $40.16 \%$ \\
\hline \multirow{5}{*}{ Aegean } & Dodecanese & 7 & 25 & $28 \%$ & 89,869 & 189,152 & $47.51 \%$ \\
\hline & Cyclades & 8 & 20 & $40 \%$ & 35,824 & 106,836 & $33.53 \%$ \\
\hline & Lesvos & 4 & 17 & $24 \%$ & 23,231 & 108,747 & $21.36 \%$ \\
\hline & Samos & 2 & 8 & $25 \%$ & 14,622 & 43,595 & $33.54 \%$ \\
\hline & Chios & 2 & 10 & $20 \%$ & 2,920 & 53,408 & $5.47 \%$ \\
\hline Subtotal & & 23 & 80 & $28.75 \%$ & 166,466 & 501,738 & $33.18 \%$ \\
\hline \multirow{4}{*}{ Crete } & Iraklio & 7 & 26 & $27 \%$ & 171,971 & 292,489 & $58.80 \%$ \\
\hline & Lassithi & 3 & 8 & $38 \%$ & 45,683 & 74,613 & $61.23 \%$ \\
\hline & Rethymnon & 4 & 11 & $36 \%$ & 10,456 & 82,956 & $12.60 \%$ \\
\hline & Chania & 4 & 23 & $17 \%$ & 22,400 & 149,703 & $14.96 \%$ \\
\hline Subtotal & & 18 & 68 & $26.47 \%$ & 250,510 & 599,761 & $41.77 \%$ \\
\hline Total & & 299 & 914 & $32.71 \%$ & $4,019,890$ & $10,843,131$ & $37.07 \%$ \\
\hline
\end{tabular}

\section{Analysis}

\section{Dividing Sample Into Categories Depending on Financial Performance}

This section of analysis aims to divide the entire sample into categories, based on financial management efficiency (efficient-inefficient Municipalities). There are two reasons for this analysis: first because of the interest that the in-depth observation of the current situation demonstrates relating to the abilities of Municipalities in financial management, and second because of how crucial it is to look into the differences in other characteristics between efficient and inefficient Municipalities. Cluster analysis was used to separate the sample into groups (L. C. Pallis \& L. P. Pallis, 2014).

In this research, three variables were used for the creation of clusters, whose descriptive details were analysed in the previous section, and which are: a Municipality's borrowing capacity, flexibility in non-investing costs, and flexibility in investment costs. These three variables were considered to be the key dimensions of efficiency in financial management; therefore, their use is illustrative of efficiency. The method used for the division is the $K$-means partitioning method. This method predetermines the number of clusters into which the sample is divided. In this research, the number of clusters was set at two because (a) theoretically, dividing Municipalities into efficient and inefficient makes more sense; (b) this number is considered to be most appropriate when the variables used for division are more than two (Kinnear \& Taylor, 
2004). The results of cluster analysis are shown in the following Tables 2 and 3.

As is shown in the cluster analysis tables, the observations that resulted from sampling can indeed be divided into two groups on the basis of the three questions above. The first cluster includes 110 Municipalities, while the second one includes 146 Municipalities. The value for the first cluster centres (central observation) was 3 for all three variables, while the value for the second cluster centres was 2 for all three variables. Considering that the potential answers to the questions used ranged from 1: very good to 4: poor, the first cluster can be named "Municipalities with inefficient financial management" and the second cluster can be named "Municipalities with efficient financial management". A cross-tabulation analysis was used to identify whether the answers to the three questions were different between the two clusters. The results of this analysis and of the relevant $x^{2}$ (Chi-square) test are shown in the following Tables 4 and 5 .

Table 2

Cluster Centers for the Three Questions

\begin{tabular}{lll}
\hline & Final cluster centers & \\
\cline { 2 - 3 } & & Cluster \\
\hline Municipality's borrowing capacity & 3 & Cluster 2 \\
Municipality's flexibility in non-investing costs & 3 & 2 \\
Municipality's flexibility in investment costs & 3 & 2 \\
\hline
\end{tabular}

Table 3

Number of Answers in Each Cluster

\begin{tabular}{lll}
\hline Number of cases in each cluster & & \\
\hline \multirow{2}{*}{ Cluster } & 1 & 110 \\
& 2 & 146 \\
\hline
\end{tabular}

Table 4

\section{Cross-tabulation Results}

\begin{tabular}{|c|c|c|c|c|c|c|c|}
\hline \multicolumn{8}{|c|}{ Cross-tab. } \\
\hline & & & \multicolumn{5}{|c|}{ Municipality's borrowing capacity } \\
\hline & & & Very good & Satisfactory & Medium & Not good & Total \\
\hline \multirow{12}{*}{$\begin{array}{l}\text { Cluster } \\
\text { number of } \\
\text { case }\end{array}$} & \multirow{4}{*}{1} & Count & 8 & 26 & 58 & 18 & 110 \\
\hline & & $\%$ within cluster number of case & $7.3 \%$ & $23.6 \%$ & $52.7 \%$ & $16.4 \%$ & $100.0 \%$ \\
\hline & & $\begin{array}{l}\text { \% within Municipality’s } \\
\text { borrowing capacity }\end{array}$ & $9.2 \%$ & $31.0 \%$ & $89.2 \%$ & $90.0 \%$ & $43.0 \%$ \\
\hline & & $\%$ of total & $3.1 \%$ & $10.2 \%$ & $22.7 \%$ & $7.0 \%$ & $43.0 \%$ \\
\hline & \multirow{4}{*}{2} & Count & 79 & 58 & 7 & 2 & 146 \\
\hline & & $\%$ within cluster number of case & $54.1 \%$ & $39.7 \%$ & $4.8 \%$ & $1.4 \%$ & $100.0 \%$ \\
\hline & & $\begin{array}{l}\% \text { within Municipality's flexibility } \\
\text { in non-investing costs }\end{array}$ & $90.8 \%$ & $69.0 \%$ & $10.8 \%$ & $10.0 \%$ & $57.0 \%$ \\
\hline & & $\%$ of total & $30.9 \%$ & $22.7 \%$ & $2.7 \%$ & $8 \%$ & $57.0 \%$ \\
\hline & \multirow{4}{*}{ Total } & Count & 87 & 84 & 65 & 20 & 256 \\
\hline & & $\%$ within cluster number of case & $34.0 \%$ & $32.8 \%$ & $25.4 \%$ & $7.8 \%$ & $100.0 \%$ \\
\hline & & $\begin{array}{l}\% \text { within Municipality's flexibility } \\
\text { in investment costs }\end{array}$ & $100.0 \%$ & $100.0 \%$ & $100.0 \%$ & $100.0 \%$ & $100.0 \%$ \\
\hline & & $\%$ of total & $34.0 \%$ & $32.8 \%$ & $25.4 \%$ & $7.8 \%$ & $100.0 \%$ \\
\hline
\end{tabular}


Table 5

Chi-square Test Results

\begin{tabular}{llll}
\hline Chi-square tests & & & \\
\hline & Value & df & Asymp. Sig. (2-sided) \\
\hline Pearson Chi-square & $90,371^{\text {a }}$ & 3 & 0.000 \\
Likelihood ratio & 107,058 & 3 & 0.000 \\
Linear-by-Linear association & 83,496 & 1 & 0.000 \\
$N$ of valid cases & 256 & & \\
\hline
\end{tabular}

According to the Chi-square test results, the answers to the three questions were different between the two clusters of Municipalities, considering that the observed significance levels were very low (close to zero). Cross tabulation shows that the frequency of the answers is very different between the two clusters and demonstrates efficient performance in financial management for the second cluster and less efficient performance for the first cluster. All the above have shown that the division of the sample into two categories of groups is actually useful. In another words, there are two types of Municipalities in Greece in relation to the ability to manage financial resources: efficient and inefficient (L. C. Pallis \& L. P. Pallis, 2014).

\section{Descriptive Measures of Variables for Municipalities With Ineffective Financial Management}

This section presents an analysis of descriptive measures for the presenting variables also used to analyze the first group of Municipalities (Municipalities with ineffective financial management). The objective is to explore the situation with respect to the administration of Municipalities in the group with the lowest financial performance and to compare it with those in the group with the highest performance. In particular, the presenting variables describe: primary problems of municipal residents, primary administrative problems, and staffing issues.

As is already mentioned in previous sections, these variables were measured by using a structured ranking questionnaire. That is, participants were asked to rank possible responses to each question on the basis of specific criteria (importance, frequency, etc.). In this section, for each possible response to each question, the number of mayors who rated it as having primary importance was calculated. Next, a table was prepared indicating frequencies and relative frequencies for each variable. Corresponding bar charts were also prepared. These are presented below (Table 6).

It is evident from the results (Figure 1), the vast majority of mayors (68\%) whose Municipalities belong to the group with least effective financial management, consider that the most important problem facing their residents is a lack of infrastructure. A much lower percentage (23\%) refers to inadequate services for business enterprises and only $9 \%$ to inadequate services for households. These percentages clearly demonstrate the primary importance of the lack of infrastructure that mayors of Municipalities falling with this category are facing. The differences observed in the relative frequencies in relation to the overall sample are very small to non-existent, signifying that the factor "financial capability" does not significantly affect participant responses.

Table 6

Biggest Problem Faced by Citizens-Municipalities With Ineffective Financial Management

\begin{tabular}{lll}
\hline Citizens' problems & Frequency & Percentage \% \\
\hline Lack of infrastructure & 73 & 68 \\
Inadequate services for households & 10 & 9 \\
Inadequate services for businesses & 25 & 23 \\
Total & 108 & 100 \\
\hline
\end{tabular}




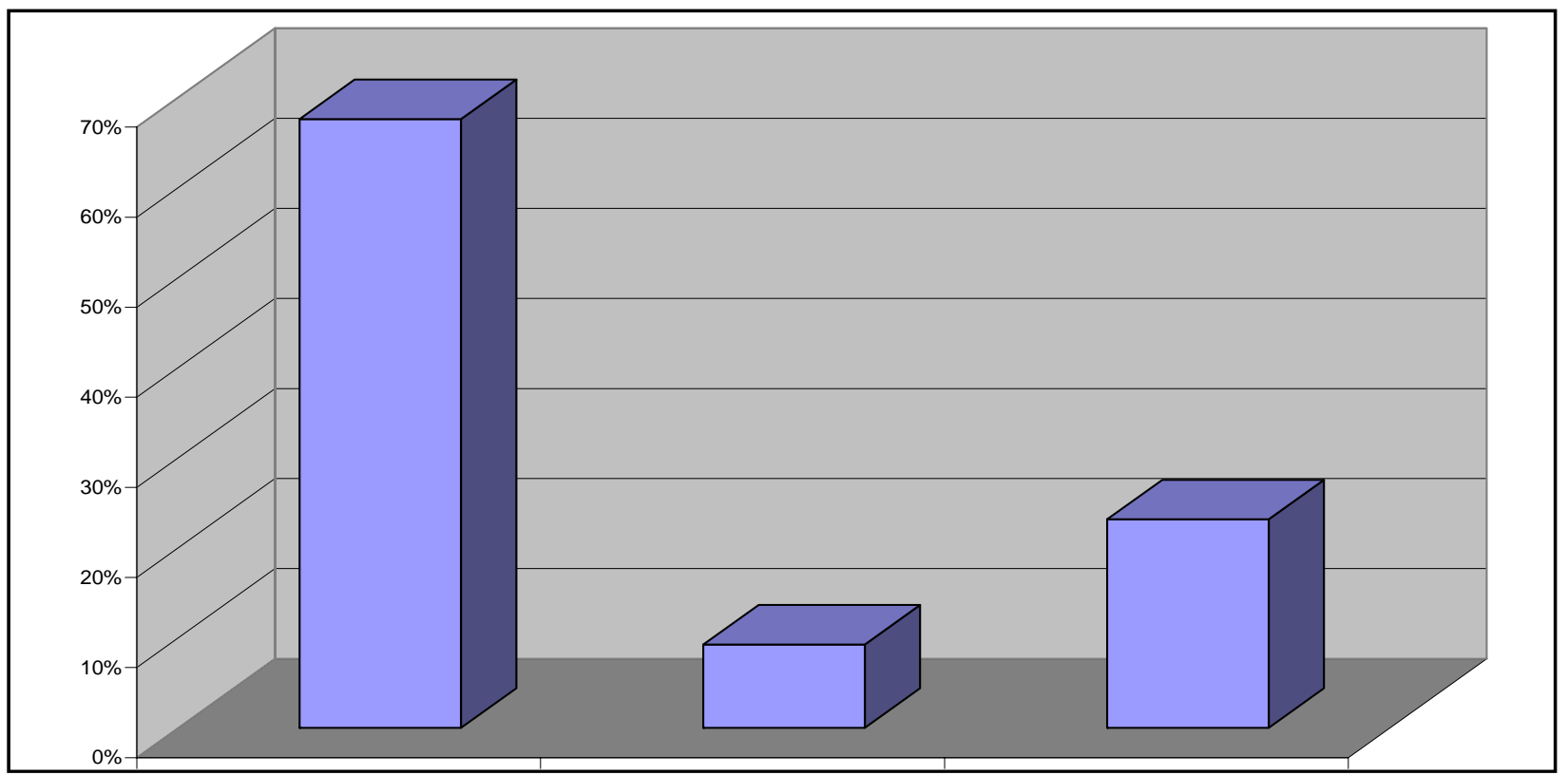

Figure 1. Biggest problem faced by citizens-Municipalities with ineffective financial management.

Table 7

Biggest Problems Faced by Municipalities in Personnel Management-Municipalities With Ineffective Financial Management

\begin{tabular}{lll}
\hline Municipalities' problems & Frequency & Percentage \% \\
\hline Inefficient administrative structure & 30 & 28 \\
Inadequate number of personnel & 20 & 18 \\
Lack of specialized personnel & 59 & 54 \\
Total & 109 & 100 \\
\hline
\end{tabular}

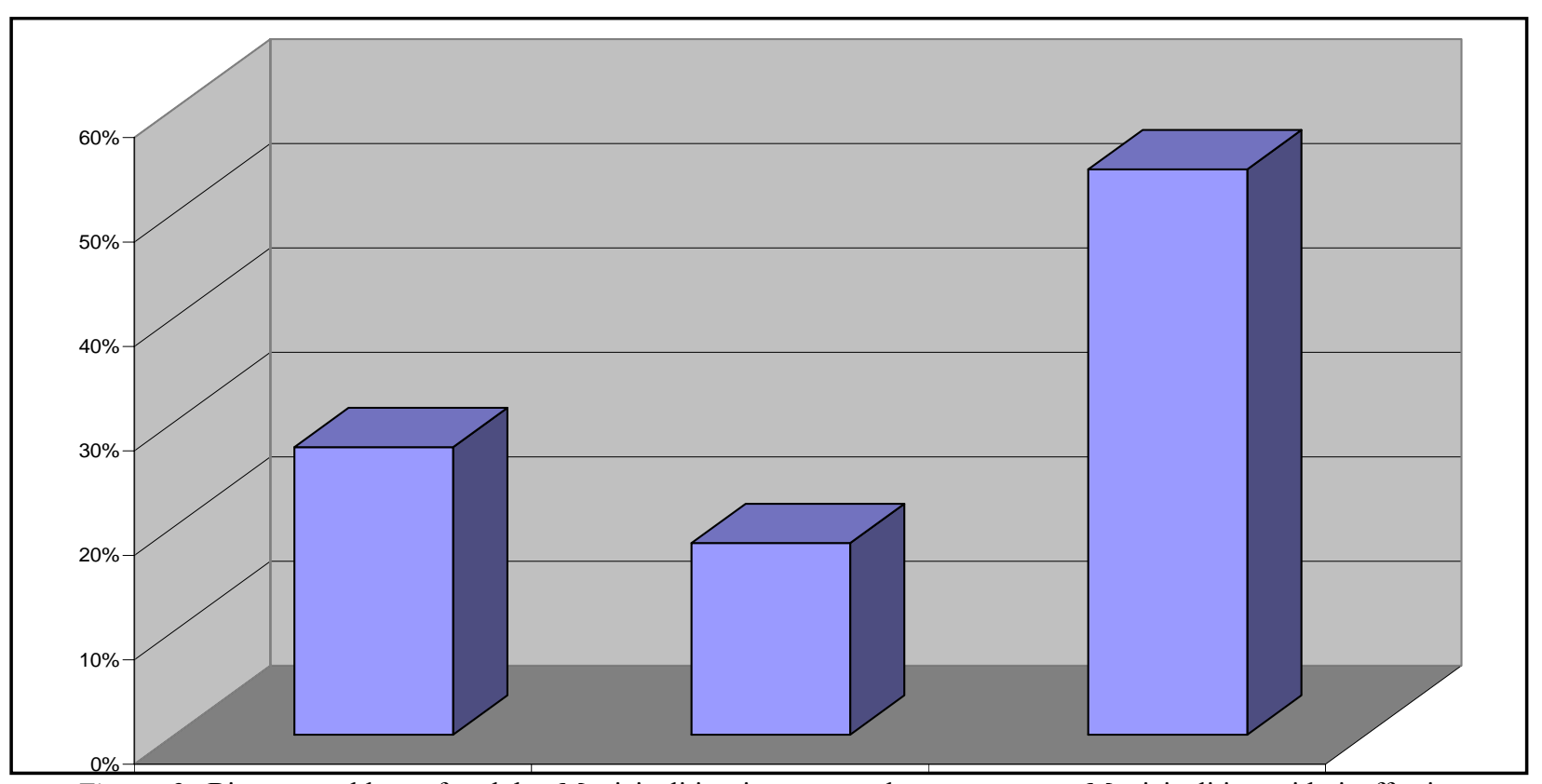

Figure 2. Biggest problems faced by Municipalities in personnel management-Municipalities with ineffective financial management. 
According to descriptive data on the second variable (Figure 2), the majority (54\%) of respondents whose Municipalities suffer from ineffective financial management consider that a lack of specialised staff is the most important problem in their Municipality. A much smaller percentage of participants considers that an ineffective organisational structure is the most important problem ( $28 \%$ of the sample), whereas a minority of the respondents (18\%) rank an inadequate number of staff as the primary problem. The results of analysis are almost identical across the overall sample, indicating that this variable is not affected by the financial capabilities of the Municipalities either.

\section{Descriptive Measures of Variables for Municipalities With Effective Financial Management}

The last section of the analysis presents the descriptive measures of the eight variables examined in the previous paragraph, this time for that group of Municipalities with effective financial administrations, to which the Municipalities with good financial performance belong. With regard to these Municipalities, as in the previous sections, for each possible response to each question of the field survey, the number of mayors giving it a first place ranking was recorded, either according to importance or any other criterion as referred to in the wording of the questions. In the next subparagraphs, Table 8 of frequencies and relevant frequencies as well as the corresponding bar chart are listed for every variable.

Table 8

Biggest Problem Faced by Citizens-Municipalities With Effective Financial Management

\begin{tabular}{lll}
\hline Citizens' problems & Frequency & Percentage \% \\
\hline Lack of infrastructure & 87 & 60 \\
Inadequate services for households & 20 & 14 \\
Inadequate services for businesses & 38 & 26 \\
Total & 145 & 100 \\
\hline
\end{tabular}

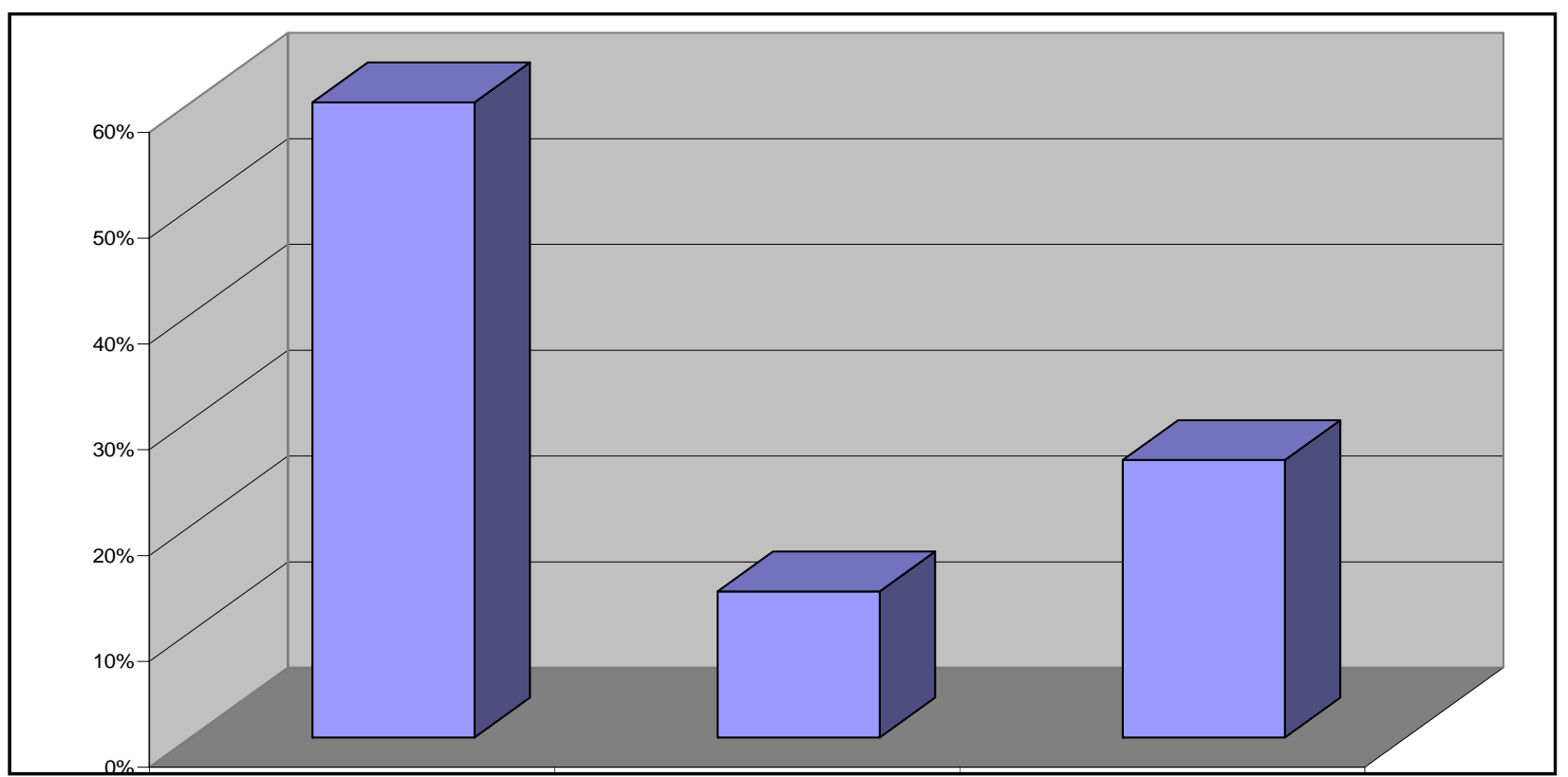

Figure 3. Biggest problem faced by citizens-Municipalities with effective financial management.

According to the responses of mayors of Municipalities with effective financial management (Figure 3), the most important problem facing their residents is inadequate infrastructure. Unsatisfactory services provided 
to business enterprises are ranked as the second most important problem and unsatisfactory services provided to households as the third. The prioritization of problems is the same for the group of Municipalities which do not have sound financial administrations. The frequency of responses differs slightly in this case and differences are not so large that financial performance can be considered to affect respondents' opinions (Table 9).

Table 9

Biggest Problems Faced by Municipalities in Personnel Management-Municipalities With Effective Financial Management

\begin{tabular}{lll}
\hline Municipalities' problems & Frequency & Percentage \% \\
\hline Inefficient administrative structure & 34 & 24 \\
Inadequate number of personnel & 32 & 22 \\
Lack of specialized personnel & 78 & 54 \\
Total & 144 & 100 \\
\hline
\end{tabular}

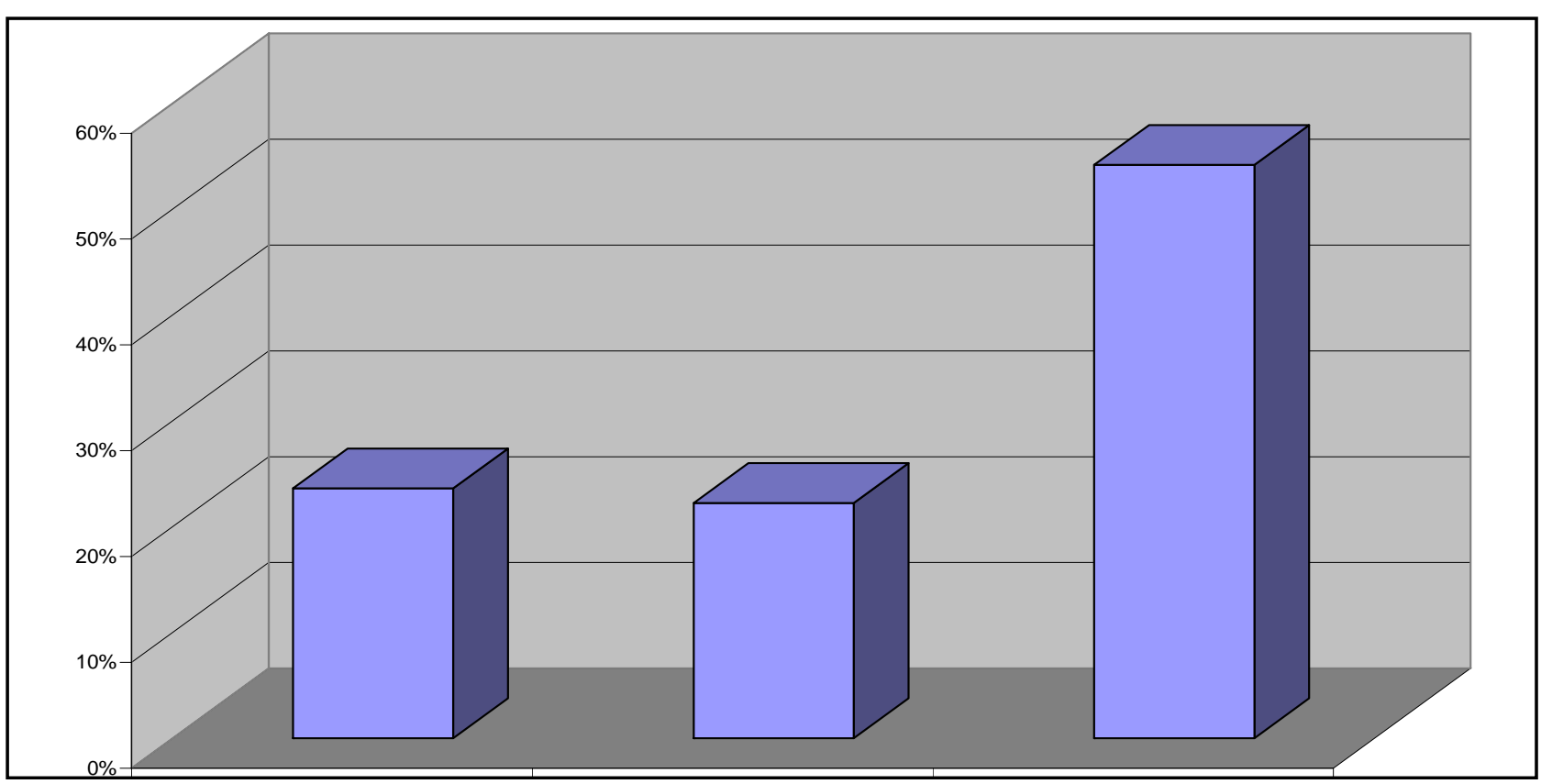

Figure 4. Biggest problems faced by Municipalities in personnel management-Municipalities with effective financial management.

With regard to staff shortages (Figure 4), the majority of mayors (54\%) of Municipalities with effective financial management consider the shortage of specialized staff to be the most important problem in their Municipality. Approximately, the same number of respondents evaluated ineffective administrative structure $(24 \%)$ and inadequate staff numbers $(22 \%)$ as being the most important problem.

\section{Conclusions}

This research attempted to divide the entire sample into categories, based on the efficiency of financial management (efficient-inefficient Municipalities). There are two reasons for this analysis: first because of the interest that the in-depth observation of the current situation demonstrates relating to the abilities of Municipalities in financial management, and second because of how crucial it is to look into the differences in other characteristics between efficient and inefficient Municipalities. Cluster analysis was used to separate the 
sample into groups. Three variables were used to create the clusters in this research: a Municipality's borrowing capacity, flexibility in non-investing costs, and flexibility in investing costs. These three variables were considered to be the key dimensions of efficiency in financial management; therefore, their use is illustrative of efficiency. As is shown from the analysis, the Municipalities were divided into two clusters, based on the three questions above. The first cluster includes 110 Municipalities (Municipalities with inefficient financial management) and the second cluster includes 146 (Municipalities with efficient financial management).

The prioritization of both problems is the same for both groups of Municipalities. The frequency of responses differs slightly, but differences are not so large that financial performance can be considered to affect respondents' opinions.

\section{References}

Athanassopoulos, A., Triantis, K., \& Schmidt, P. (1998). Assessing aggregate cost efficiency and the related policy implications for Greek local municipalities. Information, 36, 66-83.

Balaguer-Coll, N., Prior, D., \& Tortosa-Ausina, E. (2007). On the determinants of local government performance: A two-stage nonparametric approach. European Economic Review, 51, 425-451.

Bessho, S., \& Ogawa, H. (2015). Fiscal adjustment in Japanese municipalities. Journal of Comparative Economics, 43(4), 1053-1068.

Cabaleiro, R. C., Buch, E. G., \& Vaamonte, A. L. (2014). Financial situation and political parties in local governments: Empirical evidence in the Spanish municipalities. Investigaciones Europeas de Dirección y Economía de la Empresa (in English), 2(3), 110-121.

Churchill, G., \& Iacobucci, D. (2002). Marketing research, methodological foundations (8th ed.). London: Harcourt Publishing.

Cohen, S., Doumpos, M., Neofytou, E., \& Zopounidis, C. (2012). Assessing financial distress where bankruptcy is not an option: An alternative approach for local municipalities. European Journal of Operational Research, 218(1), 270-279.

De Borger, B., \& Kerstens, K. (1996). Cost efficiency of Belgian local governments: A comparative analysis of FDH, DEA and econometric approaches. Regional Science and Urban Economics, 26, 145-170.

Geys, B., Heinemann, F., \& Kalb, A. (2010). Voter involvement, fiscal autonomy and public sector efficiency: Evidence from German municipalities. European Journal of Political Economy, 6(2), 265-278.

Groves, S. M., Godsey, W. M., \& Shulman, M. A. (1981). Financial indicators for local governments. Public Budgeting and Finance, 1, 5-19.

Hooley, G., Lynch, J., \& Shepherd, J. (1990). The marketing concept: Putting the theory into practice. European Journal of Marketing, 24(9), 7-25.

Kalb, A. (2010). The impact of intergovernmental grants on cost efficiency: Theory and evidence from German municipalities. Economic Analysis and Policy, 40(1), 23-48.

Kinnear, T., \& Taylor, J. (1996). Marketing research, an applied approach. Columbus: McGraw and Hill, Inc.

Kohli, A., \& Jaworski, B. (1990). Market orientation: The construct, research propositions and managerial implications (Marketing Science Institute, report No. 90-113, Cambridge, Massachusetts).

Kumar, N., Stern, L., \& Anderson, J. C. (1993). Conducting interorganizational research using key informants. Academy of Management Journal, 36(6), 1633-1651.

Loikkanen, H., \& Susiluoto, I. (2005). Cost efficiency of finish municipalities in basic service provision 1994-2002. Urban Public Economic Review, 4, 39-63.

Nakazawa, K. (2013). Cost inefficiency of Municipalities after amalgamation. Procedia Economics and Finance, 5, 581-588.

Narver, J. C., \& Slater, S. F. (1990). The effect of a market orientation on business profitability. Journal of Marketing, 54, $20-35$.

Pallis, L. C. (2011). The institutional framework of local government finance-Analysis and perspectives (Ph.D. thesis submitted to Panteion University of Political and Social Sciences, Athens, Greece).

Pallis, L. C., \& Pallis, L. P. (2013). Analysis of key obstacles and problems faced by municipalities and their citizens: An empirical investigation in the municipalities of Greece. International Journal of Economics and Business Administration, $1(2), 33-51$. 
Pallis, L. C., \& Pallis, L. P. (2014). Separating municipalities regarding their financial performance \& financial management: An empirical investigation of the municipalities in Greece. Proceedings from International Scientific Conference eRA-9, Athens, Greece.

Papalexandri, N. (2011). The marketing of local government. Proceedings from the Information Meeting of Elected Municipalities of Attica, Athens, Greek.

Parasuraman, A., Grewal, D., \& Krishnan, R. (2004). Marketing research. New York: Houghton Mifflin.

Phillips, L. W. (1981). Assessing measurement error in key informant reports: A methodological note on organizational analysis in marketing. Journal of Marketing Research, 18, 395-415.

Ruekert, R. W. (1992). Developing a market orientation: An organizational strategy perspective. International Journal of Research in Marketing, 9, 225-250.

Silkman, R., \& Young, D. R. (1982). X-efficiency and state formula grants. National Tax Journal, 35, 383-397.

Stathakopoulos, B. (2001). Market research methodologies. Athens: Mpenou Publications.

Storto, I. C. (2016). The trade-off between cost efficiency and public service quality: A non-parametric frontier analysis of Italian major municipalities. Current Research on Cities, 51, 52-63.

Wang, X., Dennis, L., \& Tu, Y. S. (2007). Measuring financial condition: A study of U.S. states. Public Budgeting and Finance, 27, 1-21. 